\title{
PENGARUH FILSAFAT ANALITIK DALAM PENDIDIKAN BAHASA PRANCIS
}

\author{
Rohali \\ Universitas Negeri Yogyakarta \\ email: rohali@uny.ac.id
}

\begin{abstract}
(Title: Effects of Analytic Philosophy on French Language Education). Language learning cannot be separated from philosophy because philosophy is the mother of science. In its development, language learning was influenced by the philosophy that developed in his day, including analytic philosophy. The influence of analytic philosophy is strongly felt in language education, especially in semantic and pragmatic studies. The theory of logical atomism put forward by Russell has opened new horizons in the study of science, including linguistics. Meanwhile, the theory of meaning is picture, which is then continued with the theory of meaning used by Wittgenstein, is a forerunner to semantic and pragmatic studies. In addition, the analytic philosophy developed by the Oxford school has developed a theory of speech acts which naturally influences language learning, from language learning to language education as speech acts.
\end{abstract}

Keywords: philosophy, analytic, french, pragmatics

\section{PENDAHULUAN}

Sejak zaman Yunani dan Romawi, searah dengan perkembangan filsafat, bahasa memegang peranan penting. Saat itu, kajian bahasa memang belum seluas dan semendalam saat ini. Tetapi, bahasa telah digunakan oleh para filsuf, tidak hanya sebagai representasi pikiran manusia, tetapi juga sebagai kreasi akal budi manusia dalam menemukan kearifan dalam hidupnya, seperti yang dikemukakan oleh Kaelan (1998:8) bahwa filsafat merupakan aktivitas manusia yang berpangkal pada alat pikiran manusia untuk menemukan kearifan dalam hidupnya, terutama dalam mencari dan menemukan hakikat realitas dari segala sesuatu, menemukan hubungan yang sangat erat dengan bahasa terutama bidang semantik.

Perkembangan sejarah filsafat Eropa pada awal abad ke-18 sampai awal abad ke20, menurut Hidayat (2006: 41-45) dapat dikelompokkan atas dua aliran besar yaitu aliran filsafat idealisme dan aliran filsafat empirisme. Pada pertengahan abad ke-20 aliran filsafat idealisme mengalahkan filsafat empirisme yang ketika itu disebut neohegelianisme atau neoidealisme. Akan tetapi aliran ini tidak bertahan lama dan digantikan oleh aliran neorealisme yang diusung oleh Moor. Aliran neorealisme ini menitikberatkan kajian filsafat pada metode analisis bahasa, yang kemudian memunculkan istilah filsafat analitik. Dalam pandangan para filsufanalitik, analisis linguistik merupakan satu-satunya aktivitas yang sah.

Pengaruh filsafat analitik sangat terasa dalam pendidikan bahasa, terutama pada kajian semantik dan pragmatik. Teori atomisme logis yang dikemukakan oleh Russell telah membuka cakrawala baru dalam penelaahan ilmu, termasuk ilmu bahasa. Sementara itu, teori meaning is picture yang yang kemudian di lanjutkan dengan teori meaning is use oleh Wittgenstein merupakan cikal bakal kajian semantik dan pragmatik. Selain itu, filsafat analitik yang dikembangkan oleh aliran Oxford telah mengembangkan teori tentang tindak tutur yang tentu saja berpengaruh dalam pembelajaran bahasa, dari pembelajaran ilmu bahasa ke pendidikan bahasa sebagai tindak tutur. Makalah ini berupaya menelaah pengaruh aliran filsafat analitik terhadap pengembangan pendidikan bahasa.

Menurut Bakker (melalui Kaelan, 2004: 133), salah satu penyebab lahirnya filsafat analitik adalah adanya kekacauan bahasa filsafat. Banyak teori dan konsep filsafat yang sajikan dengan bahasa yang membingungkan, bahkan semakin jauh dari bahasa sehari-hari. Menurut Kaelan (1998:84) 
Filsafat analitis merupakan metode yang khas untuk menjelaskaan, menguraikan, dan menguji kebenaran ungkapan-ungkapan filosofis. Upaya menguraikan dan menguji kebenaran itu, menurut (Alwasilah, 2008: 24) hanya mungkin dilakukan lewat bahasa, karena bahasa memiliki fungsi kognitif, yaitu dengan bahasalah manusia menjelaskan proposisiproposisi yang dipikirkannya, apakah benar atau salah, sehingga ia menerima atau menolaknya secara rasional.

Tokoh tokoh aliran filsafat analitik yang berperan dan berpengaruh besar dalam mengukuhkan aliran ini antara lain George Edward Moore (1873-1958), Bertrand Russell (1872-1972), dan Ludwig Wittgenstein (1899 - 1951), serta John Langshaw Austin (1911 1960).

Pertama, Atomisme Logis Russell. Atomisme logis adalah suatu faham yang berpandangan bahwa bahasa dapat dipecah menjadi proposisi atomik atau proposisi elementer melalui teknik analisis logis atau analisis bahasa. Setiap proposisi yang ada mengacu pada bagian terkecil dari realitas. Berdasarkan pandangan yang demikian, maka kaum atomisme logis bermaksud menunjukkan adanya hubungan yang mutlak antara bahasa dengan realitas.

Atomisme merupakan salah satu aliran filsafat yang telah lama berkembang sebelum abad moderen. Di Eropa, aliran atomisme telah mulai muncul dan diperkenalkan oleh Leukippos dan Democritus sebagai muridnya pada abad ke-5 SM. Para penganut atomisme ini mengajukan teori bahwa dunia alam terdiri atas dua komponen yang tidak terpisahkan, saling berlawanan dan bersifat atomis yang tidak dapat dibagi dan diisi oleh komponen lain.

Aliran atomisme logis mulai dikenal pada tahun 1918 melalui tulisan-tulisan Bertrand Rusell. Kemudian mencapai puncaknya dalam pemikiran Wittgenstein melalui karyanya yang berjudul Tractatus Logico Philosophicus (1922) Umumnya para peminat studi pemikiran mengenal konsep atomisme logis ini melalui dua sumber kepustakaan, yaitu hasil karya Bertrand Russell yang berjudul Logicand knowledge (1901-1950) dan Tractatus Logico Philosophicus(1922) yang ditulis Ludwig Wittgenstein pada saat berkecamuknya perang dunia pertama.

Alasan Russell (2010:3) menggunakan istilah atomismelogis (logical atomism) adalah karena atom-atom yang muncul dari residu suatu analisis merupakan atomisme logis, bukan atom-atom secara fisik. Atomisme logis tersebut oleh Russell disebut dengan "partikular" seperti warna suara, unsur predikat, satuan relasional dan sebagainya. Selain itu, Russell mengemukakan istilah corak logis (logical types). Menurutnya, dua buah benda dianggap memiliki corak logis jika kedua benda itu memiliki corak yang sama (Russelle, 2010:137). Sebagai contoh, mawar dan melati memiliki corak logis yang sama karena memiliki corak yang sama yaitu corak bunga.

Kedua, Meaning is Picture. Teori tentang makna adalah gambar "Meaning is Picture" merupakan salah satu teori tentang makna yang dikembangkan oleh Wittgenstein dalam bukunya "Tractus Logico Philosophicus" (1922). Menurutnya, dunia ini dipenuhi oleh fakta-fakta, yang setiap fakta itu berhubungan dengan makna. Gambar sebagai fenomena di alam memiliki gambaran realitas. Dengan demikian, sebenarnya dunia ini dipenuhi dengan fakta-fakta, bukan oleh sesuatu.

Menurut Hidayat (2006: 37) Wittgenstein beranggapan bahwa semua tuturan manusia mengandung satu atau lebih proposisi elementer, yaitu proposisi yang tidak dapat dianalisis lagi (yang oleh Russell disebut dengan atomisme logis). Dikatakan lebih lanjut, proposisi elementer tersebut merujuk pada suatu keadaan (state of affairs) dalam realitasnya. Struktur (kalimat) dalam suatu proposisi memiliki relasi dengan struktur realitasnya, seperti gambar buah apel dengan buah apel itu sendiri. Baik teori atomisme logis yang dikemukakan oleh Russell maupun teori gambar Wittgenstein ini sebenarnya merupakan dasar-dasar pengembangan ilmu semantik yang kemudian dikembangkan oleh Eugene Nida (1911-2011) menjadi kajian semantik leksikal, dan pragmatik yang kemudian dikembangkan oleh tokoh-tokoh pragmatik seperti Searle (1932), dan Austin (1911 - 1960) 
Ketiga, Meaning is Use. Meaning is use merupakan teori yang dikembangkan oleh Wittgenstein setelah ia kembali dari Austria (negara asalnya). Sekembalinya ia mengajar di Cambridge (1929), ia mendapatkan fakta bahwa bahasa tidak hanya menggambarkan fakta-fakta tetapi juga menggambarkan maksud penutur dan bagaimana bahasa itu digunakan. Bahkan ia menentang sendiri teori meaning is picture yang dikembangkannya. Ia cenderung menganggap bahasa itu memiliki beragam fungsi. Setiap situasi yang berbeda, fungsi bahasa yang digunakan juga berbeda yang oleh Wittgenstein disebut dengan language games. Dalam bukunya Philosophical Investigations (1986), Wittgenstein menyampaikan bahwa bahasa merupakan suatu permainan, seperti halnya permainan sepakbola dan permainan lainnya yang memiliki aturan yang khas.

\section{METODE}

Tulisan ini bertujuan untuk mendeskripsikan pengaruh filsafat analitik terhadap pengembangan pendidikan bahasa Perancis di dunia. Metode yang digunakan untuk pengambilan data pada tulisan ini adalah dengan metode pustaka atau studi literatur. Data-data dan contoh-contoh diambil dari pustaka yang relevan, yaitu yang terkait dengan aliran filsafat analitik, seperti buku The Philosophy of Logical Atomism karya Russell (2010), buku karya Wittgenstein (1986) yaitu Philosophical Investigations, buku Tractatus Logico - Philosophicus karya Wittgenstein (2002), serta buku-buku dan referensi tentang pendidikan bahasa Prancis.

Analisis data dilakukan dengan cara analisis deskriptif, yaitu mendeskripsikan pengaruh filsafat analitik dalam pendidiksn bahasa Perancis. Untuk menguji keabsahan data, pada penelitian ini dilakukan triangulasi teori, yaitu dengan cara penjelasan banding suatu teori dengan teori lainnya (Moleong, 2010: 331).

\section{HASIL DAN PEMBAHASAN}

Filsafat Analitik dalam Pendidikan Bahasa

Seperti telah dijelaskan pada bagian sebelumnya, filsafat analitik telah membawa arah pendidikan bahasa dari pendekatan filsafat ke pendekatan penggunaan bahasa, tanpa meninggalkan kajian bahasa itu sendiri. Kemajuan pendekatan filsafat analitik yang dikembangkan oleh Wittgenstein dengan teori atomisme logis membawa babak baru kajian bahasa. Pandangan Wittgenstein tentang bahasa yang menyatakan bahwa analisis suatu unsur (bahasa) merupakan analisis atom-atom logis yang pada kajian bahasa berikutnya disebut dengan konstituen-konstituen pembentuk bahasa (kata, frasa, kalimat).

Sejalan dengan hal tersebut, perkembangan teori-teori bahasa di Eropa dan, Amerika, dan Inggris juga berkembang. Aliran filsafat analitik ini mempengaruhi aliran linguistik. Aliran filsafat ini sangat terasa mempengaruhi linguistik modern yang dipelopori oleh Saussure, Boas, Saphir, dan Bloomfield. Filsafat analitik ini lebih kental lagi mempengaruhi aliran linguistik fase kedua yang dimotori oleh Malinowsky yang meneliti bahasa-bahasa primitif di Eropa (1923), Trubetzkoy (1939) yang dengan aliran Prahanya mengkaji fonetik dan fonologi. Sementara itu, Weinreich (1953) mulai melebarkan kajian linguistik yang tidak lagi menelaah struktur bahasa (fonetik, fonologi, sintaksis), tetapi ke arah sosiolinguistik (kontak bahasa), yang kemudian diperkuat oleh teori fungsi bahasa oleh Roman Jakobson (1956). Teori tentang kajian semantik leksikal dikembangkan oleh Eugene Nida. Ia sebenarnya seorang linguist yang memfokuskan diri pada terjemahan Bible. Dengan ilmunya, ia mengembangkan berbagai kajian terjemahan, termasuk kajian semantik leksikal (componential analysis) pada tahun 1960-an.

Perkembangan kajian linguistik fase ketiga lebih menekankan pada kajian bahasa yang lebih variatif, mulai dari tata bahasa hingga penggunaan bahasa. Sebut saja Halliday (1961) dengan bukunya Categories of the theory of grammar, Greenberg (1963) dengan Universals of Language, dan Chomsky (1965) menulis buku Aspects of the Theory of Syntax. Perkembangan selanjutnya. Pada perkembangan selanjutnya, tokoh-tokoh seperti Labov, Halliday, dan Chomsky mengarahkan kajiannnya pada pengguaan bahasa (pramatik dan sosiolinguistik). 
Para ahli linguistik di Inggris (terutama di Oxford) sangat dipengaruhi oleh aliran filsafat analitik, terutama oleh Wittgenstein II. Mereka sangat mendukung dengan teoriteori filsafat aliran ini yang mengatakan bahwa kajian filsafat haruslah dimulai dari kajian bahasa biasa (bahasa yang digunakan seharihari) bukan bahasa logika, karena bahasa sehari-hari (ordinary language)-lah yang mencerminkan bahasa yang sebenarya. Bahasa tidak sekedar mencerminkan fakta-fakta tetapi ia digunakan untuk tujuan tertentu. John Langshaw Austin (1911-1960) merupakan salah satu tokoh linguistik yang menaruh perhatian besar terhadap penggunaan bahasa biasa. Ia dikenal sebagai Bapak kajian tindak tutur. Karya monumentalnya adalah How to do thing with word (1955) yang membahas makna dan maksud tuturan dalam suatu tindak bahasa. Buku ini dikenal sebagai buku utama kajian tindak tutur (speech acts). Tokoh lain yang juga mengembangkan teori tindak tutur adalah John Roger Searle dengan teori tindak tutur yang dibahas dalam bukunya Speech Acts: An Essay in Philosophy of Language (1969), Expression and Meaning : The Study in the Theory of Speech Acts (1979), dan Mind, Language, and Society (1998).

\section{Filsafat Analitik dan CEFR}

Dalam pendidikan bahasa Peracis, filsafat analitik menjadi dasar filosofi pembentukan Common European Framework of Reference for Languages (CEFR). CEFR adalah kerangka Kerja yang disusun oleh Uni Eropa yang memberikan dasar umum untuk penjabaran silabus bahasa, pedoman kurikulum, ujian, buku pelajaran, dan lain-lain di seluruh Eropa. Di dalam CEFR, dijelaskan secara komprehensif tindakan apa yang dipelajari oleh pelajar bahasa, bagaimana melakukannya, bagaimana menggunakan bahasa untuk komunikasi dan pengetahuan dan keterampilan apa yang harus mereka kembangkan sehingga dapat bertindak secara efektif. Deskripsi tersebut juga mencakup konteks budaya di manabahasa diatur. Kerangka ini juga mendefinisikan tingkat kemahiran yang memungkinkan peserta didik mengukur kemajuan yang akan diukur pada setiap tahap pembelajaran dan sepanjang mereka belajar (CEFR, 2001: 1).

Dalam kerangka kerja (CEFR) tersebut, pendidikan bahasa diarahkan pada dua kompetensi dasar (CEFR, 2001: 101-127) yaitu (1) kompetensi umum (general competence) yang meliputi (a) pengetahuan deklaratif (declarative knowledge) atau savoir, (b) keterampilan berbahasa dan tahu bagaimana menggunakannya (skills and know-how) atau savoirfaire, (c) kompetensi eksistensi diri (existential' competence) atau savoir-être (d) dan kebiasaan untuk belajar (ability to learn) atau savoirapprendre, dan (2) kompetensi komunikaif (communicative language competences) yang meliputi (a) kompetensi linguistik (linguistic competences) dan (b) kompetensi sosiolinguistik (sociolinguistic competence). Kompetensikompetensi yang dikembangkan dalam pendidikan bahasa asing (termasuk bahasa Prrancis) di Eropa selaras dengan aliran filsafat analitik yang menekankan bahasa biasa (ordinary language) dalam analisis bahasa dan penggunaan bahasa.

Berdasarkan kompetensi-kompetensi yang harus di kuasai pembelajar bahasa Perancis di atas, jelaslah bahwa pendidikan bahasa Perancis menekankan pada kompetensi yang integratif yaitu aspek kebahasaan dan aspek penggunaan bahasa. Kedua kompetensi itu dikembangkan dalam semua tingkatan (level) penguasaan bahasa Perancis, mulai dari tingkat dasar (A1) sampai tingkat mahir (C2).

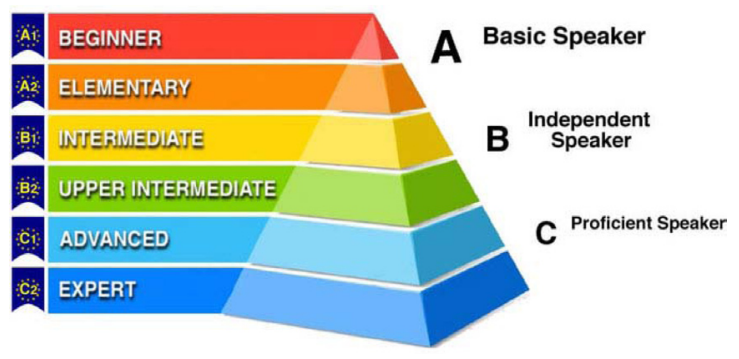

Gambar 1.

Tingkat Penguasaan Bahasa Perancis (Sumber: https://www.euro-lingual.com/english/our-teachingmethod/european-language-levels/)

Secara umum, tingkat penguasaan bahasa Perancis distratifikasikan atas tiga tingkatan yaitu (1) tingkat penutur dasar (basic speaker) yaitu mereka yang berada pada 
tingkat A1 (beginner) dan A2 (elementry), (2) tingkat penutur independen (independant speaker) yaitu para pembelajar pada tingkat B1 (intermediate) dan B2 (upper intermediate), serta (3) tingkat penutur mahir (proficiency speaker) yaitu pembelajar yang telah mencapai tingkat C1 (advanced) dan C2 (expert). Secara lebih spesifik, keterampilan penggunaan bahasa Perancis pada setiap jenjang (A1 sampai C2) dapat dilihat seperti pada Tabel 1.

\section{Pendekatan Aksional (Perspective Action- nelle)}

Sebagai implementasi dari CEFR, pendidikan (pengajaran) bahasa Prancis didasarkan pada perspektif aksional. Pada pendekatan aksional ini, Pengguna bahasa dianggap sebagai aktor sosial yang akan masuk ke dalam kehidupan sosial yang lebih luas (pribadi, pendidikan, profesional, publik) dan pembelajar dihadapkan pada sejumlah konteks penggunaan bahasa. Girardet (2011:), seorang penulis buku pelajaran bahasa Perancis dari CLE International dalam sebuah konferensi bahasa Prancis di Sao Paolo mengatakan bahwa tugas (tache) dimaksud merupakan:

Toute visée actionnelle que l'acteur se représente comme devant parvenir à un résultat donné en fonction d'un problème à résoudre, d'une obligation à remplir, d'un but qu'on s'est fixé. yaitu suatu tugas yang harus dilakukan oleh pembelajar sebagai aktor (pelaku tindakan dalam pembelajaran) sesuai

Tabel 1. Keterampilan Penggunaan bahasa Perancis Tiap Jenjang

\begin{tabular}{|c|c|c|}
\hline \multirow{2}{*}{ 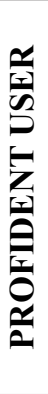 } & $\mathrm{C} 2$ & $\begin{array}{l}\text { Can understand with ease virtually everything heard or read. Can summarise information from } \\
\text { different spoken and written sources, reconstructing arguments and accounts in a coherent } \\
\text { presentation. Can express him/herself spontaneously, very fluently and precisely, differentiating } \\
\text { finer shades of meaning even in more complex situations. }\end{array}$ \\
\hline & C1 & $\begin{array}{l}\text { Can understand a wide range of demanding, longer texts, and recognise implicit meaning. } \\
\text { Can express him/herself fluently and spontaneously without much obvious searching for } \\
\text { expressions. Can use language flexibly and effectively for social, academic and professional } \\
\text { purposes. Can produce clear, well-structured, detailed text on complex subjects, showing } \\
\text { controlled use of organisational patterns, connectors and cohesive devices. }\end{array}$ \\
\hline \multirow{2}{*}{ 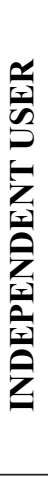 } & B2 & $\begin{array}{l}\text { Can understand the main ideas of complex text on both concrete and abstract topics, including } \\
\text { technicaldiscussions in his/her field of specialisation. Can interact with a degree of fluency } \\
\text { and spontaneity that makesregular interaction with native speakers quite possible without } \\
\text { strain for either party. Can produce clear, detailedtext on a wide range of subjects and explain } \\
\text { a viewpoint on a topical issue giving the advantages anddisadvantages of various options. }\end{array}$ \\
\hline & B1 & $\begin{array}{l}\text { Can understand the main points of clear standard input on familiar matters regularly } \\
\text { encountered in work, school, leisure, etc. Can deal with most situations likely to arise whilst } \\
\text { travelling in an area where the language is spoken.Can produce simple connected text on } \\
\text { topics, which are familiar, or of personal interest. Can describeexperiences and events, } \\
\text { dreams, hopes \& ambitions and briefly give reasons and explanations for opinions and } \\
\text { plans. }\end{array}$ \\
\hline \multirow{2}{*}{ 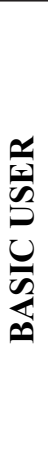 } & A2 & $\begin{array}{l}\text { Can understand sentences and frequently used expressions related to areas of } \\
\text { most immediate relevance (e.g. verybasic personal and family information, } \\
\text { shopping, local geography, employment). Can communicate in simple and } \\
\text { routine tasks requiring a simple and direct exchange of information on familiar and routine } \\
\text { matters. Candescribe in simple terms aspects of his/her background, immediate environment } \\
\text { and matters in areas ofimmediate need }\end{array}$ \\
\hline & A1 & $\begin{array}{l}\text { Can understand and use familiar everyday expressions and very basic phrases aimed at the } \\
\text { satisfaction of needs ofa concrete type. Can introduce him/herself and others and can ask and } \\
\text { answer questions about personal detailssuch as where he/she lives, people he/she knows and } \\
\text { things he/she has. Can interact in a simple way provided theother person talks slowly and } \\
\text { clearly and is prepared to help. }\end{array}$ \\
\hline
\end{tabular}


dengan masalah yang diberikan dan dipecahkan, kewajian yang harus ditunaikan, dan tujuan yang telah ditetapkan dalam pembelajaran.

Perspektif aksional memiliki ciri-ciri yang membedakannya dengan pendekatan komunikatif. Pertama, latihan-latihan dalam pembelajaran pada pendekatan komunikatif lebih bersifat simultan yaitu pembelajar berperilaku seolah-olah sebagai pelaku, dan seolah-olah sebagai bagian dari anggota masyarakat, sementara dalam perspektif aksional, pembelajar berperan sebagai pelaku tindakan atau tokoh yang sebenarnya, dan kelas sebagai masyarakat sosial. Kedua, dalam pendekatan komunikatif, tugas-tugas kebahasaan merupakan tugas komunikasi. Sementara itu, dalam perspektif aksional, tugas dalam pembelajaran tidak sebatas tugas komunikatif, tetapi juga tugas (tindakan/aksi) kehidupan bermasyarakat. Ketiga, dalam pendekatan komunikatif, komunikasi diarahkan pada tindak bahasa penutur dan mitra tutur, sementara pada perspektif aksional, tindak tutur diarahkan pada komunikasi dalam tindak sosial (l'action social) antarpenutur dan mitra tutur.

Saat ini, buku-buku pelajaran bahasa Perancis telah diselaraskan dengan CEFR dan perspektif aksional. Sebagai contoh, buku Echo, buku yang diterbitkan oleh CLE International telah disesuaikan dengan standar pembelajaran Eropa (CEFR). Buku Echo 1, sampai dengan Unite 3, merupakan bahan pembelajaran untuk A1. Buku Echo 2, sampai unite 2 merupakan bahan ajar untuk A2, dan Buku Echo 3 digunakan untuk pembelajar pada tingkat B1.

Dilihat dari konten (isi) pembelajarannya, buku Echo telah didesain sesuai dengan konten CEFR dan pendekatan aksional. Isi buku ini memuat empat kompetensi utama yaitu (a) savoir atau pengetahuan deklaratif seperti berbagai jenis prosesi pernikahan, masyarakat sosial tempat kita tumbuh, (b) savoir-faire atau ketrampilan berbahasa dan tahu bagaimana menggunakannya, seperti berpidato dan berdiskusi, (c) savoir-être atau kompetensi eksistensi diri seperti pernikahan di mana orang berciuman, ada budaya yang tidak mencium atau memeluk, ada yang berjabat tangan, ada yang tidak, dan sebagainya, dan (d) savoirapprendre kebiasaan untuk belajar seperti tema tentang berbicara dan cara menyesuaikan diri pada berbagai konteks.

Kelas didesain sebagai masyarakat sosial, sementara pembelajar dan pengajar merupakan masyarakat sosial yang saling berinteraksi menggunakan bahasa Prancis untuk menyampaikan pesan, gagasan, ide, pengalaman, dan tempat bersama-sama membangun suatu proyek (Girardet et Pecheur, 2008: 3)

\section{SIMPULAN}

Berdasarkan pembahasan pada bagian sebelumnya dapat diambil kesimpulan sebagai berikut. Pertama, aliran filsafat analitik telah mempengruhi aliran-aliran linguistik baik di Eropa maupun di Inggris dan Amerika. Kedua, CEFR sebagai kerangka kerja pendidikan bahasa-bahasa di Uni-Eropa dipengaruhi oleh aliran fulsafat analitik, baik pada tataran konseptual pendidikan bahasa, maupun pada tataran praktis pengajaran bahasa Perancis. Ketiga, perpesktif aksional, sebagai representasi CEFR mengandung empat kompetensi pokok pembelajaran bahasa yaitu savoi, savoir fare, savoir etre, dan savoir apprendre. Keempat, kurikulum, silabus dan buku-buku pelajaran bahasa Perancis seperti buku Echo, taxi, version original, dan lain-lain telah sesuai dengan CEFR CEFR dan perspektif aksional.

\section{DAFTAR PUSTAKA}

Alwasilah, A. C. (2008). Filsafat Bahasa dan Pendidikan. Bandung: Penerbit PT. Remaja Rosdakarya.

Girardet J, et Pecheur, J.(2008). Echo 2 Methode de Français. Paris: CLE International.

Hidayat, A.A. (2006). Filsafat Bahasa: Mengungkap Hakikat bahasa, Makna, dan Tanda. Bandung: Rosda Karya.

Jacky,G. (2011). Enseigner le FLE Selon une Approche Actionnelle:Quelques Propositions Méthodologiques Actes Du Xiième ColloquePédagogique De L'alliance Française De São Paulo. 
Kaelan, M.S. (1998). Filsafat Bahasa: Masalah dan Perkembangannya. Yogyakarta: Penerbit Paradigma.

Kaelan, M.S. (2004). Filsafat Analitis menurut Ludwig Wittgenstein: Relevansinya bagi Pengembangan Pragmatik. Jurnal Humaniora, Volume 16, No. 2, Juni 2004: 133 - 146.

Language Policy Unit, Strasbourg Common European Framework Of Reference For Languages: Learning, Teaching, Assessment www.coe.int/lang-CEFR. Diunduh tanggal 10 Desember 2018.

Russell, B. (2010). The Philosophy of Logical Atomism. First published in The RoutledgeClassics. London: Routledge Wittgenstein, L. (1986). Philosophical
Investigations. Reprint of English text withindex. UK: Basil Blackwell Ltd.

Wittgenstein, L. (2002). Tractatus Logico Philosophicus. Translated by D. F. Pears and B. F. McGuinness With an introduction by Bertrand Russell his edition published in the Taylor \& Francis e-Library. London and New York

https://www.euro-lingual.com/english/ourteaching-method/european-languagelevels. 